\title{
Situating Colonial Interaction and Materials: Scale, Context, Theory
}

\author{
Maxine Oland
}

As stated in the introduction, the editors of this volume bring together archaeological research from early colonial encounters in the Caribbean and the surrounding mainland. They sought original and fresh field data, and asked scholars to bring a material culture perspective to their interpretations. The result is an impressive body of work that brings into conversation case studies from a diverse set of indigenous cultural traditions.

Although the authors draw from a range of historical data, previously excavated, and recently excavated material, each foregrounds material culture as a way to understand colonial period interactions. How do the artifacts found at early colonial period indigenous sites help us understand the relationships between European, Amerindian, and African peoples? What can these objects tell us about the culture changes that resulted from these interactions? These questions fit into a larger inquiry into the role of material culture in colonial contexts, which is summarized in the introduction.

This epilogue highlights three areas of inquiry that seem critical to the case studies in this volume. What is the scale of contact and material interaction? What are the contexts in which material culture was acquired, created, and deposited? And how do we conceptualize the relationship between foreign or mixed material culture and culture change in a way that honors the indigenous peoples that made, acquired, or deposited these objects? I conclude the epilogue with a short look toward future studies, as inspired by reading these chapters.

\section{The Scale of Colonial Interaction}

Several authors stress that the material record at colonial period sites is greatly shaped by the scale, type, and frequency of colonial interaction. How long was the period of colonization? Were relationships between colonists and indigenous peoples based in exploitation, or were they on a more equal footing? Authors illustrate how interactions between indigenous and Spanish peoples 
were shaped by Europeans' economic and political goals. They also point out the longer lasting effects of these interactions on indigenous networks and political systems.

The case for scalar analysis is argued most directly by Fowler and Card, who state that archaeologies of colonialism should address Orser's (2014) "haunts" of modernity (colonialism, mercantilism/capitalism, Eurocentrism, racialization) but that we need to do so at a variety of scales. The authors suggest that we study colonial interaction at the local, regional, and global scales, and consider the length and duration of contact. Their study comparing Ciudad Vieja, the first Spanish villa in El Salvador, and Caluco, an indigenous town in the Izalcos region, illustrates the value of a multiscalar analysis, and the differences in indigenous spatial and material use at the two sites.

Mathers takes a macro-regional perspective, and argues that type of contact, frequency, and political histories of indigenous groups are crucial for understanding patterns of consumption of European goods in indigenous communities. His chapter compares the entradas of the southeastern and southwestern United States. Whereas the goals of the Spaniards and the materials they carried with them were nearly identical in each region, there have been very few Spanish goods found that were used or modified in indigenous contexts in the Southwest.

Mathers concludes that the explanations for the differences are geographical, historical, climatic, and geopolitical. The Southwest was more sparsely populated, remote, and had questionable economic value to the Spaniards, and was separated from other Spanish territories by hostile hunter-gatherer groups. Entradas were also very long, over land, and were later and less frequent than the entradas in the southeast. There were fewer indigenous settlements with large food supplies. Mathers also hints at the differences in indigenous political systems. Whereas the southeast was characterized by hierarchical chiefdoms, whose elite leaders relied on exotic foreign goods for prestige (i.e. Beck et al. 2011), the more egalitarian political systems of the Southwest did not depend on an influx of foreign goods.

As illustrated in the next section, the case studies in this volume pay careful attention to the manner and length of colonial exploitation (or lack thereof), and the ways that particular colonial contexts shaped material assemblages. Indigenous residents of a pearl fishery ranchería (Antczak et al. this volume), mining town (Ernst and Hofman this volume), or an encomienda (Valcárcel Rojas this volume) created different material patterns when relations were structured by domination than when they were structured by trade (Berman and Gnivecki this volume, Hofman et al. this volume, Keehnen this volume, Van den Bel and Collomb this volume). Similarly, residents of a colonial 
frontier, who experienced occasional visits from priests and encomenderos (Awe and Helmke this volume), interpreted and incorporated European material culture through a much different lens from those in colonial cores (Fowler and Card this volume, Sarcina this volume, Hernández-Sánchez this volume).

\section{Contextualizing Colonial Material Culture}

Most of the chapters combine an analysis of scale with detailed attention to the context of novel material culture objects and assemblages. How did European goods get into indigenous communities? How were they used, and by whom? What kinds of material changes occurred at Spanish settlements, and what can they tell us about interactions?

The case studies in this book use the careful consideration of documentary sources and archaeological data to inquire into the processes by which European artifacts were incorporated into indigenous life. They pay special attention to the scale and type of contact (how long? under what circumstances?), and to the context in which European materials were acquired and eventually found. Historical documents make explicit the ways Europeans conceptualized their relationships with indigenous peoples, and hint at indigenous motivations. The material record, when considered within the scale and context of the larger site and region, provides a window into indigenous ontologies and agentive choices.

Several chapters deal with situations of contact in which power relations between Europeans and indigenous populations were fairly balanced, or in which indigenous communities did not live under a consistent dominating European presence. For example, for the Lucayans of the Bahamas, there was only sporadic and intermittent contact until 1509, and no direct control of indigenous peoples. Berman and Gnivecki illustrate how European objects at the Long Bay site transformed European objects into indigenous ones. European objects were adopted for their aesthetics (brilliance, smell, sound, color) and their association with distant locales. Berman and Gnivecki argue that European objects were adopted because they were consistent with the Lucayan cosmovision.

Keehnen found that indigenous peoples on Hispaniola obtained European artifacts as gifts, via pilfering, by collecting, and through native exchange. Material patterns illustrate that European objects were used for indigenous purposes. Ritual caches at El Variar contained European materials, and Spanish goods were deposited in indigenous burials at Juan Dolio. At En Bas Saline, most European artifacts and foods were found in elite contexts. Keehnen 
argues that although European objects did not penetrate much of indigenous life on Hispaniola, their deposition reflects that they were controlled by elites, and played a role in the indigenous political economy of Hispaniola.

Awe and Helmke illustrate how Maya residents of the Belize frontier received European objects from Spaniards as gifts, as payment for services, as rewards for conversion, and in trade. But they also took them by forceful means, or received them indirectly through indigenous trade networks. Although much of the Belize frontier was incorporated into encomienda by 1544, the region lacked a consistent Spanish presence. European goods were largely used for Maya purposes, as status symbols for the Maya elite, or as a replacement for native exotics in Maya caches (see also Oland 2014, 2017; Pugh 2009; Pugh et al. 2012). Other European objects, such as axes and machetes, were used for mundane purposes, in addition to their deposition in elite caches.

The case study by Van den Bel and Collomb focuses on the Yao, an indigenous group that positioned itself as a middleman between the Europeans and indigenous populations of Guiana. The Yao were afraid of the Spanish, who were known for their slave raids, but maintained a free zone of trade with the French, British, and Dutch. The Yao traded European goods along their extensive Amerindian networks. Van den Bel and Collomb show that most European objects in Guiana were found in urn burials, and were transformed by Amerindians into symbolic objects of prestige. Although the exchange rate was tilted in the Europeans' favor, power relations between Amerindians and Europeans were otherwise fairly equitable. This lasted until the later seventeenth century, when the Dutch created larger settlements and took Amerindian land for the creation of sugar plantations.

As noted in many of the case studies, Spaniards gave gifts to indigenous leaders and individuals as a strategy to gain their cooperation, particularly when making initial contacts and entradas. Valcárcel Rojas points out that the "gift kit" was a product of a mercantile strategy in the Greater Antilles. Between 1503 and 1505, Spanish colonists in Cuba shifted from a mercantile to an imperial strategy of tribute collection. Gift giving went by the wayside, and Spaniards quickly shifted to a system in which they paid for indigenous encomienda labor with European goods. Valcárcel Rojas found many objects that would not be found in a traditional gift kit, such as weapons, tools, and elements associated with architecture and horses. These objects were found in indigenous settlements that were refashioned as annexes to Spanish farms, or as mining camps. Unlike the examples from many other chapters, the objects found in the Holguín province were not acquired and used according to indigenous value systems, but in a context of domination. 
Henry and Woodward's example from Jamaica shows significant material continuity at the 'Taíno' site of Maima between the precolonial and colonial period. Although there were a few nails, fragments of glass, and pieces of metal found at Maima, these likely date to the initial year of contact between the Spanish and 'Taíno,' which were characterized by more or less equitable trade relations between the two groups. Documentary sources show that subsequent relations were characterized by domination by Spaniards based at Sevilla la Nueva. Henry and Woodward therefore conclude that the lack of European material culture at Maima was due to the conscious rejection of European material culture by the 'Taíno' residents.

This chapter also provides context as to how 'Taíno' ceramics were incorporated at the Spanish settlement of Sevilla la Nueva. Henry and Woodward found that most of the Spanish households used traditional 'Taíno' ceramics, which they see as evidence of 'Taíno' women taken as wives. Only the households of elite Spaniards, found at the governor's fort, had evidence of New Seville Ware. This ceramic ware was a type of colonoware, which combined traditional 'Taíno' ceramic materials and methods, but made into Spanish styles. Unlike other chapters that deal with the blending of indigenous and European ceramic technologies (see below), the careful analysis at Sevilla la Nueva makes it clear that this technological blending took place in a context of domination and European class privilege.

The previous sections discuss the way authors use scale and context to deeply understand the relationships that led to particular material patterns. This section examines how authors couch these relationships within a larger theoretical framework. What does it mean when indigenous peoples adopt European technology, religion, or goods? How do we understand the mix of European and indigenous styles and craft techniques within the language of cultural mixing? What does it mean if the material culture remains indigenous, but the overall assemblage changes in response to colonial geopolitics? Finally, what theoretical language do we use for indigenous communities trying to maintain their political, economic, and social systems in spite of the presence of Europeans?

One of the most common forms of "mixed" objects discussed in this volume is pottery that combines both European and indigenous technological and stylistic elements. For example, Hernández Sánchez argues that potters in central 
Mexico made choices about whether to adopt, reject, or reinterpret new European technologies. She shows that potters selectively adopted glaze and majolica decoration, but not the potter's wheel. She argues that the choices potters made were not political, but were about maintaining their way of life while at the same time adapting to post-conquest society.

Fowler and Card's study of Ciudad Vieja, the first Spanish villa in El Salvador, first uses Bourdieu's structural theory of practice to understand ceramic change. The authors argue that Ciudad Vieja was an "incubator of experimentation and transformation" for the first generation of potters that experimented with new styles. Through a process of creolization the next generation created a more homogeneous style of ceramics, which were Pipil in style, but incorporated Spanish elements.

Sarcina, in contrast, uses the concept of syncretism to understand the indigenous-made pottery with European motifs found at Santa María, Colombia. This pottery was found in an indigenous context, alongside only indigenous materials. Sarcina therefore argues that this pottery was the result of experiments by local potters, who were inspired by the material culture of their masters.

Ernst and Hofman employ the concept of transculturation, which they define as the "creative, ongoing, process of appropriation, revision and survival," to understand the creation of a new pottery style in Hispaniola. Europeans did not enforce a fully Spanish way of life, and contexts of sustained interaction between indigenous, African, and European peoples, such as in mining camps, resulted in new forms of material culture.

Iverson uses Judith Butler's (1990) concept of "resignification" to challenge traditional narratives of religious conversion in her case study from Hidalgo. Iverson illustrates how indigenous religious ontologies shaped the New World church in significant ways, even though they lacked autonomy and power under the domination of the church. The indigenous residents of Tula altered the meanings and values of the church, and subtly changed it, simply by participating in the construction of buildings and the practice of rituals.

Sheptak and Joyce bring up the important point that colonial change in indigenous societies may not be expressed through foreign material culture or styles. Although the material culture at Ticamaya, Honduras, appears to be indigenous, they argue that careful attention to the assemblage reveals changes in practice. Obsidian projectile points, for example, are not in and of themselves hybrid objects, as they were found in earlier deposits at Ticamaya, and have been found in Late Postclassic and Terminal Late Postclassic deposits across the Maya lowlands (i.e. Masson and Peraza Lope 2014, 274; Oland 2013; Simmons 2002). Instead, the increase in indigenous obsidian projectile points at Ticamaya, alongside the addition of new defensive walls (perhaps 
influenced by the Spaniard turned Maya resistance fighter, Gonzalo Guerrero), represents the ethnogenesis or hybridity of a more militarized culture in response to colonialism.

\section{Discussion: Future Challenges and Possibilities}

In her chapter about religious conversion, Iverson argues that we need new narratives for understanding the colonial experience of indigenous peoples. The chapters in this volume contribute to that effort, as they contextualize material and cultural changes along the continuum of agentive choice and domination, and within the long-term historical trajectories of indigenous groups. As we move forward, however, we will have to struggle with how to create these new narratives.

What is the balance between focusing on Eurocentrism, as Orser (2012) urges, and understanding colonialism from the perspective of indigenous motivations, worldviews, and long-term histories? Many of the authors in this volume, for example, find it useful to consider the way Amerindian peoples incorporated Europeans and their objects into their own worldviews and value systems, while others are more explicit about the constraints that Europeans placed on indigenous lives and material worlds. There is a tension between these approaches that could be explored further.

How do we intentionally theorize the mixing of European and indigenous material culture elements? In his consideration of hybridity, Liebmann (2013) breaks down the backgrounds and meanings behind various theoretical conceptions of the amalgamation of indigenous and European elements in material culture. I was struck, in this volume, by how many different conceptual terms were used for pottery found with both European and indigenous features. Just as we must take care to consider the power dynamics behind the terms we use for colonial processes (Jordan 2014; Silliman 2005), we must also be aware of the implications of the ways we conceptualize colonial period material culture (Liebman 2013).

Many times throughout this volume I questioned what theoretical constructs are available for understanding the process of consuming and creating objects according to one's own value system and worldview, in spite of the presence of Europeans? Several authors in the book (Keehnen this volume, Antczak et al. this volume, Hofman et al. this volume) employ the term entanglement, seemingly as a metaphor (Silliman 2016) to describe the messy interweaving of multiple ontologies, objects, and cultures that came out of colonial interactions. 
Kurt Jordan (2009, 2014), building upon the work of Rani Alexander (1998), argues that cultural entanglement should be used to conceive of interactions in which indigenous peoples held power equal to, or greater than, European colonists. As many authors point out, the earliest colonial period interactions in the circum-Caribbean region were often characterized by equitable power relations, although these quickly shifted to more exploitative relations as the colonists' goals changed from mercantile to imperial. It may be useful to explore this term further as a way to conceptualize both colonial period relations in this region, and the material worlds that resulted from these relations.

One of the most exciting trends in this volume is the move away from binary models that position indigenous/colonized peoples in opposition to Europeans/colonizers. The reality was almost always far more complicated, and included competition between European powers, the personal goals of individual European conquerors, multiple and often competing indigenous groups and individuals, and African slaves and their descendants.

Ernst and Hofman, for example, see the mix of African, Spanish, and indigenous influence in the pottery of Hispaniola. Van den Bel and Collomb's chapter recognizes that European trade in Guiana was shaped by indigenous trade networks, as much as by the competition between the Spanish and other European powers in Guiana. Mathers' chapter brings attention to the native allies brought from Mexico on Southwest entradas, some of whom stayed in Zuni communities. The fact that colonial Mexican pottery, made by indigenous potters, was modified and used in Hawikku graves complicates the colonizer/colonized binary in exciting ways.

The chapter by Hofman, Hoogland, Boomert, and Martin shows how the southern Lesser Antilles was a space contested by both Amerindian groups and multiple European powers. Their work is meaningful for contemporary Kalinago peoples whose origins have been contested, and suggests the potential and need for more collaboration between contemporary populations and archaeologists studying colonialism in this region. Amerindian groups can challenge narratives of erasure through the creation of archaeologically based heritage sites.

The chapters in this volume point us forward toward the creation of new narratives that do not deny the horrific realities of colonial loss, but also honor the creativity and adaptability of indigenous and enslaved peoples. At the same time, they break down simplistic and binary definitions of colonialism. The diversity of concepts and theoretical constructs in the volume are in part tied to the tremendous diversity present in the contexts, scales, and situations of colonial interaction in this region. Future scholarship will include conceptual and theoretical models that challenge the limiting binary of colonizer and colonized/European and indigenous, paying increased attention to the 
role that enslaved and free Africans, their descendants, and indigenous allies of Spanish conquistadores, played in colonial interactions. It will also include efforts to use the results of archaeological studies for meaningful heritage work with contemporary descendants of indigenous and African peoples.

\section{References}

Alexander, Rani. 1998. "Afterword: Toward an Archaeological Theory of Culture Contact." In Studies in Culture Contact, edited by John G. Cusick, 467-795. Center for Archaeological Investigations Occasional Paper No. 25. Carbondale: Southern Illinois University.

Beck, Robin A. Jr., Christopher B. Rodning, and David G. Moore. 2011. "Limiting Resistance: Juan Pardo and the Shrinking of Spanish La Florida, 1566-1568." In Enduring Conquests: Rethinking the Archaeology of Resistance to Spanish Colonialism in the Americas, edited by Matthew Liebmann and Melissa Murphy, 19-39. Santa Fe: School for Advanced Research Press.

Butler, Judith. 1990. Gender Trouble: Feminism and the Subversion of Identity. New York: Routledge.

Jordan, Kurt A. 2009. "Colonies, Colonialism, and Cultural Entanglement: The Archaeology of Postcolumbian Intercultural Relations." In International Handbook of Historical Archaeology, edited by David Gaimster and Teresita Majewski, 31-49. New York: Springer.

Jordan, Kurt A. 2014. "Pruning Colonialism: Vantage Point, Local Political Economy, and Cultural Entanglement in the Archaeology of Post-1415 Indigenous Peoples." In Rethinking Colonial Pasts through Archaeology, edited by Neal Ferris, Rodney Harrison, and Michael V. Wilcox, 103-120. Oxford: Oxford University Press.

Liebmann, Matthew. 2013. "Parsing Hybridity: Archaeologies of Amalgamation in Seventeenth-Century New Mexico." In The Archaeology of Hybrid Material Culture, edited by Jeb J. Card, 25-49. Center for Archaeological Investigations Occasional Paper No. 39. SIU-Carbondale: Center for Archaeological Investigations.

Masson, Marilyn A. and Carlos Peraza Lope. 2014. Kukulcan's Realm: Urban Life at Ancient Mayapán. Boulder: University Press of Colorado.

Oland, Maxine. 2013. "The 15th-17th Century Lithic Economy at Progresso Lagoon, Belize." Lithic Technology 38 (2): 81-96.

Oland, Maxine. 2014. "'With the Gifts and Good Treatment that He Gave Them': Elite Maya Adoption of Spanish Material Culture at Progresso Lagoon, Belize." International Journal of Historical Archaeology 18 (4): 643-667.

Oland, Maxine. 2017. "The Olive Jar in the Shrine: Situating Spanish Objects within a 15th-17th Century Maya Worldview." In Indigenous People and Foreign Things: 
Archaeologies of Consumption in Native America, edited by Craig N. Cipolla, 127-142. Tuscon: University of Arizona Press.

Orser Jr, Charles E. 2012. "An Archaeology of Eurocentrism." American Antiquity 77 (4): 737-755.

Orser Jr, Charles E. 2014. A Primer on Modern-World Archaeology. Clinton Corners: Eliot Werner Publications.

Pugh, Timothy W. 2009. "Contagion and Alterity: Kowoj Maya Appropriations of European Objects." American Anthropologist 111 (3): 373-386.

Pugh, Timothy W., Jose Romulo Sanchez, and Yuko Shiratori. 2012. "Contact and Missionization at Tayasal, Peten, Guatemala." Journal of Field Archaeology 37 (1): 3-19.

Silliman, Stephen W. 2005. "Culture Contact or Colonialism? Challenges in the Archaeology of Native North America." American Antiquity 70 (1):55-74.

Silliman, Stephen W. 2016. "Entanglements of Colonial Encounters and Social Inequality: Disentangling the Archaeology of Colonialism and Indigeneity." In Archaeology of Entanglement, edited by Lindsay Der and Francesca Fernandini, 31-48. London and New York: Routledge.

Simmons, Scott E. 2002. "Late Postclassic-Spanish Colonial Period Stone Tool Technology in the Southern Maya Lowland Area:The View from Lamanai and Tipu, Belize." Lithic Technology 27 (1): 47-72. 